John C. Weicher

John C. Weicher is a senior fellow at the Hudson Institute and a visiting scholar at the Federal Reserve Bank of St. Louis. Heidi L. Beyer provided research assistance.

\title{
The New Structure of the Housing Finance System
}

\begin{abstract}
A 25 YEARS OF ECONOMIC evolution and 15 years of political turmoil, the U.S. housing finance system has changed in fundamental ways, and the structure of the new system is becoming apparent. The system is still intended to allocate credit to housing and hold mortgage rates below their free-market level, but this subsidy is provided through different institutional arrangements. The dominant institutions are now extremely large government-sponsored enterprises (GSEs) which operate in the secondary mortgage market, issuing securities that are backed by mortgages and buying mortgages originated by other institutions. They have taken the place of small local savings and loan associations which make loans directly to homebuyers and hold the mortgages in their own portfolios. The cost of the subsidy falls on taxpayers who bear the risk of failure by the GSEs.

The public purpose of government intervention in the housing finance system has always been to promote homeownership, giving force to a social preference that derives from a widely held but rarely analyzed belief that homeowners are better citizens, because they "have a stake in society." Subsidies are appropriate because families will not take this social benefit into account in deciding whether to buy a home. The system also has two subsidiary goals: (1) countercyclical support for housing production; and (2) geographic equity (as defined by public policy) in the mortgage
\end{abstract}

market. The latter is more directly related to the purpose of promoting homeownership.

Achieving these purposes is the responsibility mainly of privately owned institutions which are supposed to meet them while maximizing profit and avoiding direct cost to taxpayers. This is also true of the major housing finance agencies within the federal government; they do not normally receive funds from the U.S. Treasury. The private as well as public institutions operate under statutes which define their powers, limitations and privileges, and delineate what they can hold as assets and liabilities. To some extent, they compete against each other.

The home mortgage market consists of some $\$ 3$ trillion of household debt, nearly all of it held by private institutions, of which more than $\$ 1$ trillion is explicitly or implicitly guaranteed by the federal government (not counting deposit insurance). There is continuing tension between the public purposes of the system and the safety and soundness-and profits-of the privately owned institutions that predominate in it.

This paper first describes the present structure of the housing finance system, contrasting it with the traditional system and explaining why the system has changed. It concludes with a discussion of the major issues that will face public policy over the next few years. 


\section{WII CURRENT SVSTRM}

\section{Morkgrge and Housing Morkets}

The mortgage market has traditionally been separate from other capital markets, because mortgages differ in key respects from other debt instruments. A home mortgage is a loan to an individual or couple for the purpose of buying a particular house. The amount the lender is willing to loan depends on the value of the property. The mortgagor promises to repay the loan over time. If he or she fails to do so, thus defaulting on the mortgage, the lender can foreclose, take title to the property, and sell it to someone else. The default risk (also termed credit risk) depends on changes in the value of the property and in the circumstances of the owner, such as job loss, divorce, or the death of a husband or wife. The extent of loss in the event of default depends on changes in property values. Real estate markets are local markets, so evaluating a particular piece of property requires local expertise. For these reasons, mortgages have traditionally been illiquid; investors have been willing to buy them only if they have the knowledge required to evaluate them.

The standard mortgage instrument - until the 1980 s, almost the only mortgage instrument-is a fixed-rate, level-payment, long-term, self-amortizing loan. The term usually runs for 30 years. Such mortgages carry prepayment risk as well as default risk. The term can be shortened only at the option of the borrower, by prepaying the loan. If market interest rates fall, as happened most recently during 1993-94, mortgagors are likely to prepay their loans and refinance their homes at a lower interest rate. If rates rise, mortgagors are unlikely to prepay unless they are moving, and lenders will find themselves earning belowmarket rates on their mortgage portfolios. Thus, lenders bear the risk of adverse movements in interest rates. This was a particular problem during the inflation of the late $1970 \mathrm{~s}$. As a result, mortgages with adjustable rates (ARMs) were authorized and became common in the early 1980s. A variety of other new instruments also have come into existence, such as balloon mortgages, which are not fully amortized over their term, and graduated payment mortgages, which carry fixed interest rates but have lower payments in the early years. The traditional standard mortgage remains the most common, although its popularity relative to ARMs has varied as interest rates have fluctuated. Fixed-rate mortgages are more popular among borrowers when the general level of interest rates is low and ARMs are more popular when the level is high.

The dominant position of the standard mortgage developed under the auspices of the federal government, specifically the Federal Housing Administration (FHA), which was created in the 1930 s to insure home mortgages. Buyers pay a mortgage insurance premium to FHA, and in return FHA guarantees that lenders will receive payment of the outstanding principal balance on the mortgage in the event of default and foreclosure. FHA is required by law to operate on an actuarially sound basis; its insurance premiums are supposed to cover its losses and operating costs. Once FHA demonstrated the viability and profitability of such mortgages, the "FHA mortgage" also became the norm for conventional mortgages (those not insured or guaranteed by a government agency).

\section{Prinary Lenders}

The local nature of real estate markets has meant that mortgage lenders have traditionally been local institutions. The most important have been the savings and loan associations (S\&Ls), both in terms of their share of the mortgage market and the share of mortgages in their portfolios. The S\&Ls started as local specialized mortgage portfolio lenders, obtaining deposits from "small savers" within their locality and making mortgage loans there also. Until 1983 their lending areas were geographically limited by statutes and regulation. Typically, their deposits have been locally generated as well, though there has been no geographic limitation on liabilities. Mutual savings banks, concentrated in the Northeast, are similar to S\&Ls as specialized mortgage portfolio lenders, but they developed independently and started with a different purpose: to provide a range of financial services to households. Savings banks and S\&Ls together are usually termed "thrifts." They have access to the national capital markets through the Federal Home Loan Bank System, a set of 12 regional Federal Home Loan Banks which they own. Chartered and regulated by the federal government, the Home Loan Banks are able to borrow at preferential rates in the capital markets. Commercial banks also hold a significant share of home mortgages, but mortgages comprise a minor fraction of their assets. Until 1989 they could not belong to the Home Loan Bank System; they now can if their mortgage holdings are large enough. 
S\&Ls, mutual savings banks and commercial banks are primary lenders; they originate mortgages which they hold in their own portfolios. A large number of mortgages, however, are originated by mortgage bankers, for immediate sale in the secondary market to an investor who expects to hold them. Mortgage bankers make their money from fees for originating mortgages and often for servicing them, collecting the monthly payments and transmitting them to the investor. Mortgage banking developed as an important component of the housing finance system when FHA began to insure mortgages. FHA insurance and its uniform national underwriting standards meant that specialized knowledge of local housing markets was less important for investors. Mortgage bankers have since developed the skills necessary to originate conventional mortgages and now originate just under half of all home mortgages.

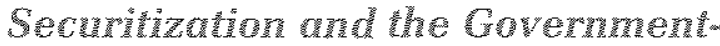 Sponsored Enterprises}

The limitations of mortgages as investment vehicles led to the creation of mortgage-backed securities (MBSs) beginning in 1970. Mortgage securitization consists of combining a group of mortgages into a pool and selling shares in the pool to investors. This spreads the risk of default over a number of mortgages and allows investors to calculate the probability of default for the mortgages in the pool with more accuracy than for any individual mortgage. The earliest and simplest MBSs are known as pass-through securities; the servicer collects principal and interest payments and passes them through, without taxation, to the investor.

The pass-through security does not reduce prepayment risk. More recent forms, the Collateralized Mortgage Obligation (CMO) and the Real Estate Mortgage Investment Conduit (REMIC), partition the principal cash flow from a pool of mortgages or MBSs into maturity classes, or tranches. Each investor receives a propor tionate share of all interest payments. Principal payments are allocated in full as they occur to each tranche in turn, starting with the shortestmaturity tranche. Tranches are separately priced and sold to investors with different time horizons. Investors in the longer-term tranches incur greater interest rate risk, but have some protection against prepayment. They are not, however, protected in the event of a protracted decline in interest rates; if mortgagors prepay in large numbers, the securities will be redeemed. This type of security was developed in 1983 and it now accounts for about half of all mortgages that are securitized. ${ }^{1}$

Securitization has broadened the mortgage market by creating instruments that appeal to investors without special knowledge of local housing markets. The payment streams are similar to bonds, and the consequences of default and prepayment are minimized.

Until the last few years, the market for MBSs has generally required a government guarantee on the mortgages, the securities, or both. Securitization was developed by a government agency, the Government National Mortgage Association (GNMA or Ginnie Mae). GNMA issued pass-through securities based on pools of FHA-insured mortgages, and added its own guarantee of timely payment of principal and interest to the FHA guarantee of principal payment in case of default. (GNMA also issues securities backed by pools of mortgages guaranteed by VA, originally the Veterans Administration and now the Department of Veterans Affairs, in a program created after World War II and modeled on FHA.)

The other major MBS guarantors are the housing GSEs: the Federal National Mortgage Association (FNMA or Fannie Mae) and the Federal Home Loan Mortgage Corporation (FHLMC or Freddie Mac). ${ }^{2}$ Both also buy and hold mortgages in their own portfolios, financing them by issuing debt securities in the capital markets, and in fact they have the first- and fourth-largest mortgage portfolios, respectively, of all mortgage lenders in the United States. They are secondary market agencies; they do not originate mortgages but buy loans from primary lenders or mortgage bankers.

FNMA and FHLMC are privately owned institutions with stockholders and private boards, but they are federally chartered corporations with a variety of special privileges, and the President appoints five members out of 18 to the board of each one. The most important of the privileges are exemption from state and local
1 The collateral for CMOs and REMICs can be either whole mortgages or MBSs. Thus, the ratio of CMOs and REMICs to all MBSs does not represent either their share of all MBSs or their share of all securitized mortgages.
${ }^{2}$ GNMA can also be considered a GSE, but it is fully owned by the federal government and operates as an agency within HUD, as is FHA. 
income taxes, exemption from Securities and Exchange Commission registration and state securities laws, the ability to borrow $\$ 2.25$ billion from the U.S. Treasury in an emergency, and the fact that their debt securities are "qualified investments" for regulated financial institutions. Their securities are also issuable and payable through Federal Reserve Banks. ${ }^{3}$

These privileges give them "agency status" in the capital markets, a general perception that the government will stand behind them. This perception is reinforced by the fact that both are very large financial institutions, "too big to fail." Agency status allows them to borrow at relatively low rates and to issue or guarantee payment on securities based on pools of conventional mortgages. The market treats their guarantees of timely payment of principal and interest as equivalent to a government guarantee. ${ }^{4}$

\section{The Role of the Federal Government}

It should be clear that the federal government has a large role in the housing finance system. It insures some mortgages; it issues securities backed by pools of those mortgages; and it has chartered corporations which are believed in the capital markets to have an implicit government guarantee behind their debt securities and their mortgage securities. In addition, it regulates and insures the deposits of primary lenders, and has chartered institutions which provide them with access to the capital markets. The federal government is generally credited with conducting three successful social experiments in the mortgage market: demonstrating the feasibility of long-term, self-amortizing loans; mortgage insurance; and securitization. In all three cases, the private sector has successfully copied the federal models. The FHA mortgage became the standard for conventional mortgages, and a private mortgage insurance industry has developed to insure them. The private sector now accounts for more business than the federal government in both instances. The demonstration that securitization is feasible has been followed by a sub-

${ }^{3}$ Most of these privileges date back in some form to the FNMA Charter Act of 1954 or its initial 1938 charter. In 1970 the same privileges were extended to FHLMC when it was created.

4 The securities may be issued directly by a GSE or alternatively by a subsidiary of a private entity such as a Wall Street firm, with the GSE guaranteeing the timely payment of principal and interest.

${ }^{5}$ These statements are based on unpublished tabulations of FHA-insured loans beiween 1989 and 1992. The tabula stantial volume of private MBS activity only since about 1990 , however, and private securities are still a small part of the total market.

\section{The Dividing Lines}

The federal government also demarcates the market segments of the various institutions by means of two statutory numerical concepts: the FHA ceiling and the conforming loan limit.

The FHA ceiling is the maximum principal balance on a mortgage that FHA can insure. The ceiling is set in law in nominal dollars; since 1980 higher amounts have been allowed in areas with higher housing costs. The present ceiling is $\$ 67,500$, or 95 percent of the area median home price if that is higher, up to a maximum of $\$ 151,725$. The maximum is still less than 95 percent of the area median home price in a number of large markets, among them New York and the largest metropolitan areas on the West Coast, and it is raised every few years.

FHA insurance is intended for the first-time homebuyer who can only afford a relatively small down payment, and who thus poses a greater risk of default to the lender. Most FHA buyers make a down payment of five percent or less. ${ }^{5}$ Below the ceiling, nearly all low down payment loans are insured by FHA and securitized by GNMA.

The conforming loan limit is the maximum principal amount of a mortgage that FNMA and FHLMC can buy. Before 1974 , they were restricted to mortgages with principal amounts below the FHA ceiling. A higher limit was set by statute in that year. In 1977 the limit was set at 25 percent above the maximum mortgage amount for S\&Ls, and both were raised in 1979 . After the S\&L maximum was abolished in 1980 , the conforming loan limit was set by statute at its then-current value of $\$ 93,750$, and indexed on the basis of the annual percentage change in the mean price of homes bought with conventional mortgages. Since 1980, the limit has been about 37 percent above the mean price. In 1993 tions differ from published data because FHA allows part (before 1991, all) of the closing costs to be financed in the mortgage, as is discussed in Price Waterhouse (1990, pp. 18-19). The published data do not adjust the loan-to-value ratios to reflect financing of closing costs, and therefore show somewhat lower loan-to-value ratios. Fof example, Pfice Waterhouse (1990, p. 17), reports that in 1988-89 stightly less than half of FHA-insured mortgagors had loanto-vatue ratios above 95 percent 
the conforming loan limit was $\$ 203,150$, while the mean price was $\$ 144,000{ }^{6}$

Because of their agency status and the perception that they are too big to fail, the GSEs can offer lower interest rates than the S\&Ls and therefore dominate the market below the conforming loan limit. Estimates of their cost advantage are in the range of 20 to 35 basis points. ${ }^{7}$

The S\&Ls remain as portfolio lenders above the conforming loan limit. Below the limit, they operate largely as mortgage bankers. They originate mortgages not for their own portfolios but for sale to the GSEs, although they may buy back the securities issued on a pool of the mortgages that they have sold. Regulations issued under the Financial Institutions Reform, Recovery and Enforcement Act of 1989 (FIRREA) gave the S\&Ls an incentive to move away from portfolio lending by setting capital requirements only 40 percent as high against MBSs issued by the GSEs as against whole mortgages. Other thrifts and commercial banks have a similar role.

The mortgage market, therefore, can be divided into the FHA/ GNMA submarket, for low down payment loans below the FHA ceiling; the GSE submarket, for most other loans below the conforming loan limit; and the "jumbo" submarket, occupied by S\&Ls, other thrifts and commercial banks, for loans above the conforming loan limit.

Actual market segmentation, however, is less clear-cut than the dollar demarcations suggest. The FHA ceiling only applies to FHA. The GSEs, the S\&Ls and any other lender can originate mortgages below the ceiling, and some such loans are made. To some extent, the private mortgage insurers compete with FHA by offering insurance on loans with low down payments, though they do not insure a large share of these mortgages.

Similarly, the conforming loan limit applies only to the GSEs. The S\&Ls and other primary lenders can make loans below the limit. But the conforming loan limit is much less restrictive on the GSEs than the FHA ceiling is on FHA. Since house prices in most years rise at least modestly, mortgages that were above the limit when issued may be below it a few years later. Thus, the share of the market open to the GSEs is larger when measured in terms of all outstanding mortgages than it is when measured in terms of mortgages originated in the current year. Primary lenders do make loans below the conforming loan limit. Some are nonstandard loans which the GSEs do not choose to purchase, but mortgages above as well as below the limit are likely to be underwritten to the guidelines of the GSEs, to keep open the option of selling them in the secondary market.

In addition, the conforming loan limit apparently only adjusts in one direction. Declining house prices during 1993 resulted in a reduction of $\$ 6,050$ in the calculated conforming loan limit for 1994, as reported by the Federal Housing Finance Board. FNMA and FHLMC announced that they would not lower the limit, because the 1980 statute referred only to "increases," and not to "decreases" or "changes." HUD Secretary Henry Cisneros, as GSE regulator, first challenged this action and then accepted it.

\section{THE GROWING DOMINANCE OF THE GSES}

The GSEs have been the thriving and expanding institutions in the system. In 1992, the latest year for which full data are available, FHA and VA loans were about 10 percent of the total dollar volume of all home mortgages issued, nonconforming loans about 20 percent, and conventional conforming loans about 70 percent. The dominant role of FNMA and FHLMC in the conforming loan market is reflected by the fact that they securitized over half of these loans and added to their mortgage portfolios as well.

The growth of the GSEs is shown in Table 1, which depicts the mortgage market in terms of the total dollar volume of loans outstanding at various dates. The GSEs now hold or securitize about 30 percent of the total, compared to about 7 percent in 1980 . Since 1980 they have accounted

\footnotetext{
${ }^{6}$ The annual adjusiment is based on the percentage change in prices of homes sold during the last five business days in October.

7 See, for example, ICF (1990) and Hendershot: ard Shilling (1989). The former estimates a differential of 23 basis points as of 1987 , the latter 30 to 35 basis points as of 1986 . Both apply to loans that are al least 15 percent above the conforming loan limit and, therefore, unlkely to be sold in the secondary market when they are seasoned. These are apparently the most recent analyses.
}
s The staff director of the Senate Housing Subcommittee as of 1980 has stated that the intent of the statute was that the limit should move in accord with house prices in both direc- tions, but prices had risen so long and so much by 1980 that nobody remembered the possibility of a decrease when the bill was written.


Table 1

\section{Single-Family Mortgage Debt Outstanding, 1968-92 (end-of-year values)}

Dollar Values (billions of current dollars)

\begin{tabular}{|c|c|c|c|c|}
\hline & 1968 & 1980 & 1989 & 1992 \\
\hline \multicolumn{5}{|l|}{ Portfolio lending } \\
\hline FMA portiolio & 7 & 52 & 91 & 124 \\
\hline FHL MC portiolo & 0 & 4 & 18 & 31 \\
\hline 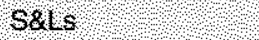 & 110 & 411 & 512 & 375 \\
\hline Oonmercial banks & 39 & 160 & 336 & 452 \\
\hline Ohers' & 109 & 229 & 529 & 591 \\
\hline Sublotal & 265 & 856 & 1486 & 1573 \\
\hline \multicolumn{5}{|l|}{ Security holdings" } \\
\hline s8ls & 0 & 27 & 200 & 159 \\
\hline Conmerclal bonks & 0 & 20 & 129 & 307 \\
\hline Ohers & 0 & 63 & 592 & 914 \\
\hline Subtotal & 0 & 110 & 921 & 1380 \\
\hline \multicolumn{5}{|l|}{ Securities issued't } \\
\hline FNMA MBSS & 0 & 10 & 220 & 486 \\
\hline FHUMCPCs & 0 & 14 & 266 & 402 \\
\hline GNMA MBSS & 0 & 92 & 858 & 411 \\
\hline Priatepools & 0 & 4 & $\checkmark 77$ & 132 \\
\hline Sublotat & 10 & 110 & 921 & 1380 \\
\hline lotal & 268 & 965 & 2408 & 2954 \\
\hline
\end{tabular}

Percent Shares

\begin{tabular}{|c|c|c|c|c|}
\hline & 1968 & 1980 & 1989 & 1992 \\
\hline \multicolumn{5}{|l|}{ Portlolio lending } \\
\hline fNuA portolo & 26 & 64 & 38 & 42 \\
\hline FHLMc portiolo & 00 & 04 & 07 & 10 \\
\hline S\&LS $\checkmark \checkmark \checkmark \checkmark)$ & 415 & 42.6 & 213 & 127 \\
\hline Conmerclaloonks & 14.7 & 16,6 & 140 & 15.6 \\
\hline Oherst $४$ ४ ४ & 411 & 237 & 220 & 200 \\
\hline Subrotal & 1000 & 887 & 617 & 533 \\
\hline \multicolumn{5}{|l|}{ Security holdings": } \\
\hline $88 \mathrm{LS}$ ४४ ४४ ४४ ४ & 0.0 & 28 & 88 & 5.4 \\
\hline Commercial banks & 00 & 19 & 54 & 104 \\
\hline Ohers? & 00 & 6,5 & 24.6 & 310 \\
\hline Sublotal & 00 & 114 & 382 & 46.7 \\
\hline \multicolumn{5}{|l|}{ Securities issued? } \\
\hline $\mathrm{ANM} A \mathrm{MBSS}$ ४ & 00 & 000 & 91 & 148 \\
\hline $1441 \mathrm{POS}$ & 00 & 15 & 114 & 13.6 \\
\hline GMMAMBSS & 00 & 96 & 14.9 & 139 \\
\hline Private pools & 00 & 04 & 32 & 4.5 \\
\hline Subtotal & 00 & 114 & 382 & 467 \\
\hline
\end{tabular}

T Others ncilde nulual savings banks, Ite insurance companies, thance companies, the farmers tome Administration the Federal Houstng Administration, the Veterbns Administraton (Deparment of Veterans Aftairs in 1989 and later), mortgage conpanies, leal estate investrient trusts, state and local credtagencles, state and lo ca retirement funds, goninsured pension Unds, credil unions, ohner U.S govemnent agences, and huviduals.

*3 Security holdings show the distribution of secunties issued. Either can be added to portiolo lending data to obtain the totals; both cannot be added without double counting security holdings can be added to data on polfolio lending to shou mortgage. market activity of hirfis, batks and other institutions, secunitles issued can be added to data on porttollo lendilg to show mont: gage narket activity of the GSES:

SOURCES. Board of Governors, US, Gepariment of Housing and Urban Development Inside Mongage Capital Markets, hside Nortgage Securites Savings and Loan Fact Book

for over 40 percent of the net increase; since 1989 , over 70 percent. This is nearly the entire con ventional conforming loan market. The new interpretation of the conforming loan limit allows them to further increase their market share.

FHA and VA insure or guarantee a gradually declining share of home mortgages, as Table 2 shows. It is not feasible to calculate nonconforming loans as a fraction of the outstanding stock of mortgages at any given time. The nonconforming market has been stable at about 20 to 22 percent of all conventional mortgages originated in a given year, measured in terms of dollar volume, but there has been a fairly steady shrinkage when measured in terms of the number of mortgages, from 11.6 percent in 1984 to 6.4 per- cent in 1993. Even the stable dollar share of annual originations implies a declining share of all mortgages outstanding, as the conforming loan limit rises from year to year.

The housing finance system is an emerging duopoly, dominated by the two large GSEs. Other institutions are increasingly limited to segments of the market which are effectively barred to the GSEs by statute, and which are declining in importance.

The dominant position of the GSEs is reinforced by their relationship to other market institutions. Thrifts and banks are both their competitors and their customers. They compete as portfolio lenders, but at the same time they sell 


\section{Table 2 \\ Government-Guaranteed and Conventional Mortgages, 1968-92

\begin{tabular}{|c|c|c|c|c|}
\hline & 1968 & 1980 & 1989 & 1992 \\
\hline \multicolumn{5}{|c|}{$\begin{array}{l}\text { Dollar Values } \\
\text { (bilitions of curent dollars) }\end{array}$} \\
\hline $\mathrm{FlA}$ & 51 & 94 & 283 & 326 \\
\hline $\mathrm{VA}$ & 34 & 102 & 157 & 164 \\
\hline Conventional & 180 & 70 & 1968 & 2464 \\
\hline $\mathrm{Total}$ & 265 & 965 & 2408 & 2954 \\
\hline \multicolumn{5}{|c|}{ Percent Shares } \\
\hline $\mathrm{PHA} P$ & 19.2 & 97 & 118 & 110 \\
\hline VA & 128 & 106 & 65 & 5.6 \\
\hline Conventonal & 679 & 798 & 817 & 834 \\
\hline
\end{tabular}

Source Dept of Housing \& Urban Dovelopment, Surey of Motgage Lending Actinty

mortgages to the GSEs and buy mortgage securities from them, and also buy the debt securities that the GSEs use to finance their portfolios.

\section{Th TRADTIONAL SYSTEM: A COMPHESON}

This is very different from the housing finance system as it existed about 25 years ago. In 1968 it was still recognizably the New Deal system. It was dominated by the S\&Ls, which gathered deposits locally, borrowed from the Home Loan Banks during recessions or when rates were high, and made long-term, fixed-rate loans (up to a maximum of $\$ 40,000$ ) on homes located within 50 miles of their home offices (100 miles after 1964). The Federal Home Loan Bank Board the Bank Board) regulated and supervised both the S\&Ls and the Home Loan Banks, and insured the S\&Ls through the Federal Savings and Loan Insurance Corporation (the FSLIC).

FHA was losing business to the S\&Ls, and at the same time taking on greater credit risk, because of the growing private mortgage insurance industry. FHA had a single premium for all loans; on the "principle of cross-subsidization," profits on the less risky loans were supposed to subsidize losses on those with higher loan-to-value ratios. The outcome was that FHA lost the better loans to the conventional market, because private mortgage insurers could charge a lower premium on the less risky loans. ${ }^{9}$

The only secondary market agency was FNMA, established in 1938 as a fully governmental agency and limited to FHA and VA mortgages. Its purpose was to smooth out the flow of mortgage credit, over time and between places. Securitization had not yet been invented; FNMA issued bonds and bought mortgages from primary lenders and mortgage bankers. It was supposed to be a dealer, selling as well as buying mortgages. It had begun to operate as a portfolio lender in the post-war period, however, buying VA mortgages in particular, until directed to liquidate its portfolio by the 1954 FNMA Charter Act. Its portfolio then fluctuated between $\$ 2$ billion and $\$ 3$ billion until 1965. At that point it again began to buy mortgages in large volume. Its portfolio reached $\$ 7$ billion in 1968 , less than 3 percent of the total market.

This system was considered a success in terms of its policy objectives. Housing production reached unprecedented levels in the postwwar period; the pre-war peak of 937,000 housing starts in 1925 was eclipsed in 1946 and indeed in all later years. There was also a remarkable increase in homeownership, from 44 percent of all households in 1940 to 55 percent in 1950 and 62 percent by 1960 . Total home mortgage debt doubled in the first five years after the war and doubled again in the next five years. Not all the goals were met; regional differences in mortgage rates probably did not diminish, but this was a secondary concern. ${ }^{0}$ Contemporary economists were divided over whether the housing finance system was a major contributor to these outcomes, or whether the same results could have been reached some other way, but as a policy matter the system was credited with the successes that occurred."

\footnotetext{
9 This paragraph is based on Kaserman (1977).

${ }^{10}$ See Fredrikson (1971) and the data and literature therein cited on changes in regional differentials. Actual average mortgage rates varied by about 1 percentage point between the Northeast at the low end and the South and West at the high end, and may have risen slightly between 1940 and 1963. These rates are not risk-adjusted, but Fredrikson makes adjustments for loan-to-value ratio and term, and finds they have little effect on the regional differentials.
} 
Several problems were inherent in this system, and by the late 1960 s it was already starting to break down. The S\&Ls were expected to incur interest rate risk routinely. They borrowed short and they had to lend long. If interest rates rose, their cost of funds would rise faster than the earnings on their long-term mortgage portfolios. Second, they operated under a kind of one-way Glass-Steagall Act. They had no protection from competition on either side of the balance sheet. They could issue only time deposits and had to specialize in home mortgages. Commercial banks could, however, also issue time deposits and make mortgage loans. Third, the geographic lending restrictions meant that S\&Ls incurred credit risk from local as well as national economic changes. This had already occurred on a large scale when the Florida land boom collapsed in the late 1920s. ${ }^{12}$

\section{CHANGES IN THF SYSTEM}

All these potential problems became real ones after 1965 and forced changes in the system. The disintegration that began with the onset of inflation in the late 1960 s has been described and analyzed by many economists. ${ }^{13}$ In this paper only a brief review of the process of change is necessary. Table 1 traces its course. It shows the importance of different institutions in the mortgage market in 1968, as the New Deal system was starting to unravel: in 1980, when policymakers were forced to recognize that the S\&Ls could no longer function as portfolio lenders in an inflationary world; in 1989, when FIRREA was passed to address the losses of the S\&Ls and the insolvency of the FSLIC; and in 1992, the latest year for which information is available.

\section{Inflation and the Decline of the S\&LS}

The S\&Ls remained the dominant institutions in the mortgage market during the 1970s. They held over 40 percent of all home mortgages in
1980 as they did in 1968, and they accounted for almost half of the net increase in mortgages outstanding over the period. But this was increasingly against their will. Once inflation began to accelerate, they could not finance their portfolios of fixed-rate long-term mortgages with short-term deposits, unless depositors would accept below-market rates. The small saver proved unwilling to subsidize the homebuyer, if alternative investments paying market rates were available. Money market mutual funds (MMMFs) were such an investment. Beginning in 1972 the S\&Ls' cost of funds began to rise relative to short-term Treasury rates. ${ }^{14}$ By 1980 the net income of the S\&Ls as a whole was approaching zero, tangible net worth was starting to fall, and the industry had a net worth in market value terms variously calculated to be between -8 and -19 percent of its assets. ${ }^{15}$

Major legislation was enacted in 1980 and 1982 that liberalized both the asset and liability sides of S\&L balance sheets. The goal of saving them as institutions took precedence over the goal of promoting housing. They were allowed to make loans and direct investments outside of housing altogether, up to 40 percent of their assets. Between 1980 and 1989, they accounted for less than a quarter of the increase in outstanding mortgages, and more than half of their growth took the form of security purchases rather than portfolio lending. By 1989 they held only about 30 percent of outstanding mortgages either in portfolio or as securities. Since the passage of FIRREA, closure of failed S\&Ls has reduced the total portfolio of the industry by over $\$ 175$ billion, and their share of the market is now under 20 percent.

\section{The Evolution of the Secondary Market}

The dates in Table 1 also represent stages in the evolution of the secondary market. Between

12 Between 1927 and 1929, 40 percent of the S\&Ls in Florida, with almost half of the assets, went out of business, while S\&Ls in the rest of the country were expanding. See Bodfish (1931) tor these data.

3. For analyses of the problems of the S\&Ls during the $1970 \mathrm{~s}$ and 1980s, see Barth (1991) and White (1991); White was a member of the Federal Home Loan Bank Board and Barth was chtef economist there during the late 1980s. Jones (1979) describes the policy process during the 1970s. The most extensive analysis of the secondary market is U.S. Department of Housing and Urban Development (1987). Weicher (1988) describes the changes in the system as a whole and the developing problems that led to the passage OF FIRREA.

14 The Eleventh District Cost of Funds rose from 9 basis points below the three-month Treasury rate in 1972 to 61 basis points above it in 1987. (The Eleventh District Federal Home Loan Bank is located in San Francisco and the district includes the states of Arizona, California and Nevada. Its Cost of Funds, measuring the interest rate on deposits paid by S\&Ls in the district, is one of the common indices for ARMs.)

${ }^{15}$ See, for example, Brewer (1989), Brumbaugh (1988) and Kane (1985). Brewer's estimate is the lowest, Kane's the highest. Brumbaugh's is -12.5 percent. 
1968 and 1980 , the secondary market took on its present institutional structure, securitization was invented, and the first mortgage securities won market acceptance.

Two legislative changes-me in 1954 requiring FNMA to buy mortgages on privately owned low-income housing projects subsidized by the government, and the other in 1967 treating the purchases as a federal budget outlay-resulted in splitting FNMA into two agencies in 1968 and changing its role. ${ }^{16}$ GNMA was created to take responsibility for the low-income mortgages, and FNMA went off-budget as a federally chartered corporation with agency status in the capital markets.

In 1970, amid concerns about rising interest rates and a new "credit crunch" in the primary mortgage market as a result of Reg Q, policymakers responded by turning to the secondary market. In the Emergency Home Finance Act of 1970, FNMA was given authority to buy conventional mortgages as well as those guaranteed or insured by the federal government. At the same time, the S\&Ls acquired their own federally chartered secondary market facility, the Federal Home Loan Mortgage Corporation (FHLMC). FHLMC was supposed to buy the S\&Ls' current conventional mortgage portfolios to "free up" funds for new loans-in effect trying to shift the consequences of monetary policy to other sectors of the economy. Like the Home Loan Banks, FHLMC was wholly owned by the S\&Ls. ${ }^{17}$

Thus, where there had been one secondary market agency in 1967, there were three in 1970. They had different ownership and they acted in different ways.

GNMA operated as a secondary market agency very much in the original intent of the New Deal system. It did not buy and sell mortgages, but it achieved the same result by issuing securities.

\footnotetext{
16 Under the 1967 federal budget reform, purchases of subsidized mortgages were raising outlays on a dollar-for-dollar basis, even though part of the principal and interest on the mortgage would be paid to the government by the borrower. Subsequent budget reforms have changed this accounting practice. Under current law, the entire principal amount of a mortgage purchased or insured by the federal government is counted in the credit budget, but only the anticipated subsidy is included as a outlay in the administrative budget.

${ }_{17}$ Opposition to allowing FNMA to buy conventional mortgages was stated by Federal Reserve Chairman Martin in 1969 and opposition to creating FHLMC was stated by Federal Reserve Chairman Burns in 1970. Martin expressed concern that FNMA's conventional mortgage portfolio would be illiquid and, therefore, might ultimately displace FNMA's
}

It created the first MBSs in 1970 ; by 1980 it was securitizing virtually all new FHA and VA loans, and its MBSs accounted for almost 10 percent of all outstanding mortgages. FHLMC followed GNMA into the securities business on a much smaller scale and became primarily an issuer of MBSs backed by conventional mortgages. FNMA took a different route. During the 1970s, it turned itself into the largest conventional mortgage portfolio lender and thus, in effect, the largest S\&L in the country, albeit with different sources of funds. Its experience paralleled that of the S\&Ls. It did not foresee the infiation of the 1970 s, so that its net worth also turned negative in the late 1970s: its 1980 value of -16 percent was similar to the S\&L industry. ${ }^{18}$

During the 1980s, securitization accounted for over half the growth in the total volume of mortgage credit. In 1981 both FNMA and FHLMC initiated mortgage swap programs, buying S\&L portfolios and issuing pass-through securities on exactly the same mortgages in return. This brought FNMA into the business of issuing securities, rather belatedly. Since then, both its portfolio and its MBS volume have grown rapidly. Its outstanding MBSs are now 3.5 times the size of its portfolio, but it remains the largest portfolio lender. Besides issuing pass-throughs to S\&Ls, FHLMC created the CMO in 1983 and expanded its securities business almost twentyfold.

FIRREA marks a further stage in the evolution of the secondary market. It turned FHLMC into nearly a carbon copy of FNMA, giving it exactly the same kind of board of directors and a very similar charter. After FIRREA, the secondary market institutions assumed a dominant position in the mortgage market. Between 1968 and 1980 , about 80 percent of the net increase in mortgages was held in portfolio and 20 percent was securitized; since 1989 the proportions have been

holdings of FHA and VA mortgages, and also that FNMA's debt issuances would drive up interest rates and raise the cost of funds to the S\&Ls and other primary mortgage lenders. Burns raised the issue of illiquidity and expressed concern that FHLMC would drive up interest rates on FHA and VA mortgages. See U.S. Department of Housing and Urban Development (1987).

${ }^{8}$ U.S. Department of Housing and Urban Development (1987), based on Kane and Foster (1986). 
reversed. GSE portfolios also continued to grow as a share of the market.

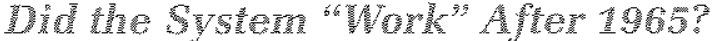

Housing advocates opposed many of the policy changes for fear they would weaken the ability of the system to allocate credit to housing, regardless of the consequences for the financial system or the economy. This was the key concern preventing financial reform in the 1970s: If the S\&Ls were allowed to diversify, who would "fill the gap" in the mortgage market? This concern proved to be unfounded. The secondary market agencies filled the gap, as Table 1 shows, and the volume of outstanding mortgages almost tripled between 1980 and 1989.

A second concern was the cost of mortgage credit. This too has proved to be largely unfounded. The spreads between mortgage and bond rates may have widened during the 1970 s and early 1980 s, but by the late 1980 s the conventional mortgage market may have become fully integrated with the capital markets. ${ }^{19}$ Here also, the growing role of the GSEs offset the declining presence of the S\&Ls, holding down the mortgage rate in the conforming loan market.

Regional differences in mortgages rates probably disappeared by the mid-1980s, as a result of securitization and deregulation. Available data on interregional flows of mortgage funds suggest that securitization resulted in transfers from the Northeast and Midwest to the South and West, where population and housing demand were growing, and, as already noted, in 1983 the S\&Ls were allowed to make mortgage loans anywhere in the country. ${ }^{20}$ The developing $\$ \& L$ crisis in the 1980 s also helped create a national mortgage market. One way in which the Bank Board handled failing S\&Ls was to sell them for their franchise value to other S\&Ls - at first in the same market, then in the same state, then in other states, as the number and severity of failures rose and the financial resources of the FSLIC were increasingly inadequate.

The system had less success in achieving its other purposes. Since 1965 the homeownership rate has fluctuated in a fairly narrow range, between 62 and 66 percent of all households. ${ }^{21}$ There was a notable increase among young families during the 1970s, but this was simply a result of inflation. Young families bought homes as soon as they could because owning a home was the best inflation hedge available, especially as inflation pushed them into higher marginal tax brackets. In the 1980 s disinflation and reductions in marginal tax rates caused their homeownership rate to drop quickly back to its 1970 level.

Housing cycles, like economic cycles in general, became more pronounced. Record years of over 2 million housing starts annually in 1971-73 were followed by a postwar low in 1975; another year of 2 million in 1978 was followed by new lows in 1981 and 1982. The housing finance system could not have been expected to offset completely the effects of the oil shocks and other macroeconomic changes, but it is doubtful if it achieved its stated more modest objective of mitigating their impact on housing and shifting part of the consequences to other sectors. The S\&Ls used advances from the Home Loan Banks to offset deposit outflows, and this may have had some effect. FNMA may also have mitigated the cycles to a lesser extent through the late 1970s, but it was not aggressively countercyclical, and it may have had no effect in the recessions of 1980

${ }^{19}$ Hendershott and Van Order (1989) conclude that the interest rate on conventional, fixed-rate mortgages rose by about 100 basis points between the late 1970 s and the mid-1980s, compared to the rate that would have prevailed in a perfect market; then it fell by about 50 basis points between 1986 and 1988 to the market rate. Other studies covering a shorter period and comparing the mortgage and bond rates also find that the conventional mortgage rate began rising in relative terms sometime in the 1970 s, before deregulation of the S\&LS. See, for example, Kaufman (1981), Tuccillo, Van Order and Villani (1982) and Hendershott, Shilling and Villani (1983). The Hendershot and Van Order study ends in 1988 , and there does not appear to be any more recent analysis of the spread; given the year-to-year fluctuations in the spread which they calculate, it would be desirable to see more recent data before concluding that the actual conventional conforming loan rate is the same as the rate in a perfectly competitive market. Cotterman (1994) notes that the spread between the MBS and Treasury rates fluctuated between 1984 and 1990, and was at its lowest level in 1988 and 1990

20 Rudolph, Zumpano and Karson (1982) find that interregional interest rate differences still existed in the mid-1970s, while Karson, Rudolph and Zumpano (1986) conclude that they did not exist by the mid-1980s. King and Andrukonis (1984) report that FHLMC securities generated a gross transfer of over $\$ 5$ billion during their first decade. Information on net interregional flows of mortgage funds is not available, but the existence of substantial gross flows suggests that securitization played a significant role in eliminating regional rate differentials.

21 The difference in the trend after 1960 may be partly attributable to demographic changes, especially the increasing proportion of households in categories in which homeownership is less commor, such as single individuals and single parents 
and 1981-82.22 FNMA's purchases of conventional mortgages dropped by about one-third from 1979 to 1981 , which does not suggest that it tried to act countercyclically.

Thus, even during this period of institutional change and upheaval, the system continued to allocate credit to housing, albeit at somewhat higher mortgage rates, and a fully national mortgage market developed. But cyclical fluctuations in housing were severe and the homeownership rate stopped rising, raising the question of whether the system was still achieving its basic purpose.

\section{POLICY ISSUES: SAFETY AND SOUNDNESS VS. PUBLIC PURPOSE}

The housing finance system continues to evolve. Congress has enacted three major laws in the last five years, affecting every institution in the system, and may consider further legislation for the Federal Home Loan Bank System. ${ }^{23}$ Some important provisions of these laws have not yet been implemented; when they are, they may in turn provoke further changes. The laws have addressed two kinds of issues: policy matters-what purposes the system will serve and how it will achieve them; and regulatory matters--what powers different institutions will have and how they will be regulated.

In the policy area, all three new laws represent a balancing of public purpose against "safety and soundness," the implicit objective that the system not impose direct costs on taxpayers that must be met by legislated appropriations. In the wake of the S\&Ls' problems, there has been a much stronger emphasis on safety and soundness; new capital requirements have been imposed on most institutions within the system. But there are elements in each law that concern the public purposes, and there is some evidence that the pendulum may be swinging back toward a renewed emphasis on these purposes. At the same time, some provisions of the new laws may make it more difficult to achieve them.

\section{Safety and Soundness}

The new laws raise capital standards and take account of risk differentials among assets for virtually all institutions within the housing finance system. FIRREA imposed more stringent capital requirements on the S\&Ls. They must have 1.5 percent tangible capital relative to assets and must meet the same risk-based capital standards as national banks. The tangible net worth of the S\&Ls as a whole was only 0.7 percent in 1989.

Both FHA and the GSEs are required to hold more capital than they had when the laws were passed. The existing standards were not raised so much as they were changed conceptually. FHA had no specific capital standard, beyond the legislative requirement that it be actuarially sound, which was undefined. FNMA's capital requirement, established in its Charter Act, was calculated as a debt-to-capital ratio. This meant that it was only required to hold capital against its portfolio. Because it did not need to issue debt to finance its MBSs, FNMA's capital-to-asset ratio (including MBSs) was 1.1 percent in 1990. Prior to FIRREA, FHLMC had no statutory capital requirement; the Bank Board determined it as a policy matter. FIRREA gave FHLMC the same debt-to-capital standard as FNMA. With its larger proportion of MBSs, its capital-to-asset ratio was 0.8 percent in 1990 . These are quite low levels of capital; had the GSEs been required to meet the risk-based capital standards set for the S\&ls in FIRREA, FNMA would have needed 2.5 times as much capital as it actually had in 1990 , and FHLMC more than three times as much, ${ }^{24}$

Both the FHA and GSE standards are established by "stress tests." In other words, the entity must

Congress required and received nine separate reports from various federal government agencies.)

earlier cycles, and Kaufman (1985) for the 1980-82 recessions. Grebler analyzes both Home Loan Bank advances and FNMA purchases.

23 The three laws are: FRREA, concening the S\&LS, the Federal Home Loan Bank Board (which it abolished), FHLMC, and to a lesser extent the Federal Home Loan Banks; Title 5 of the National Affordable Housing Act of 1990, concerning FHA; and the Federal Housing Enterprises Financial Safety and Soundness Act of 1992, enacted as Title 13 of the Housing and Community Development Act of 1992, concerning FNMA and FHLMC. In addition, Congress in 1992 required five separate studies of the Federal Home Loan Bank System as the precursor to future legislation. Four of these studies appeared during 1993, and the fifth in Apri 1994. (The GSE legistation in 1992 was enacted after
${ }^{24}$ The calculations of these various capital ratios are reported in U.S. Department of Housing and Urban Development (1990a, 1990b). The published debt-to-capital ratios in the reports include only stockholders' equity; on that basis, the ratios are 0.8 percent for FNMA and 0.6 percent for FHLMC. Regulatory capital is defined in the Charter Acts to include retained earnings and subordinated debt. Subordinated debt is not counted as equity under Generally Accepted Accounting Principles because it takes precedence during bankruptcy over ownership interests. The subordinated debt of the GSEs is due and payable in the event of bankrupicy or insolvency, which appears to limit the government's ability to rely on it as capital. 
have enough capital to survive a recession, with the amount determined in advance by econometric analysis. Both are risk-adjusted capital standards; riskier loans are more likely to default and more capital is required against them.

The FHA standard was set on the basis of an actuarial study by Price Waterhouse during 1989-90. Price Waterhouse recommended that FHA should at a minimum have a net worth of 1.25 percent against insurance in force, instead of the then-current level of about 1.0 percent. The purpose was to ensure that FHA would have positive net worth in the event of a typical post-war recession. This standard was enacted in 1990 , to be effective in 1992 , with a higher standard of 2.0 percent in the year 2000 . To reach these targets, the insurance premium was raised by about 70 percent, in present value terms, and risk-related premiums were established for the first time. Minimum equity requirements for FHA homebuyers were also raised, to reduce defaults and strengthen the insurance fund; this increase, however, was partly rolled back in $1992 .{ }^{25}$

The GSE stress test is based on their worst actual regional experience, which for both has been Texas in the mid-1980s. They are supposed to have enough capital to withstand such a recession if it occurred on the national level, and also to survive large (600 basis points) upward or downward changes in interest rates occurring within a period of one year and lasting for 10 years. Both mortgages held in portfolio and MBSs are included.

The GSE capital standard includes more than the stress test. It also defines two lower levels of capital, in the form of ratios against mortgages held in portfolio and MBSs. The authority of the regulator varies depending on the GSE's actual capital relative to the levels defined in the statute. The "minimum" capital level is 2.5 percent against mortgages held in portfolio and 0.45 percent against MBSs, which matched FNMA's

25 The 1990 legislation required $\mathrm{FHA}$ mortgagors to have at least 2.25 percent equity in their home when they bought it (1.25 percent for mortgages under $\$ 50,000$ ). Previously, it was possible to buy a home with no real equity, because buyers were allowed to finance the closing costs in their mortgage. On loans below $\$ 50,000$, the minimum down payment is 3 percent; on loans over $\$ 50,000$, it is 3 percent of the first $\$ 25,000$ and 5 percent over $\$ 25,000$. Closing costs average 2 to 3 percent, ranging up to 6 percent in a few states. The down payment in effect paid the closing costs for a substantial number of FHA-instured homebuyers. For analysis of the relationship between defauts and initial actual capital position as of 1991, and was slightly more than FHLMC's capital. (FHLMC was given 18 months to meet the minimum level without incurring any regulatory sanctions, and it now does.) The "critical" capital level is half of the minimum level; if capital falls below it, the regulator can immediately put the GSE into receivership.

The GSEs' risk-based capital standard is almost certainly less stringent than the standard for thrifts and banks, and the minimum standard clearly is lower. Depository institutions must have 4 percent capital against a mortgage in their portfolio, while the GSEs must only have 2.5 percent. If a mortgage is securitized by the GSEs and the security is held by a thrift or bank, total capital is still less: 2.05 percent, consisting of 1.6 percent for the depository institution to protect against interest rate risk and 0.45 percent for the GSE to protect against credit risk.

The FHA and GSE standards were established in very different ways. In the case of FHA, an econometric analysis was conducted and the results were known before legislation was passed. The law set new parameters for FHA insurance partly on the basis of whether they would enable FHA to achieve the standard. In the case of the GSEs, the stress test is prescribed as much as possible in the statute, but it was not performed before the bill was passed. Instead, it was negotiated between the Bush Administration and the GSEs and written into law by Congress without analysis of how much capital will be required to meet it. The test must be formally stated in regulations by November 1994, and does not become effective for another year.

Capital standards for the Federal Home Loan Banks may be the subject of legislation in the near future. Their capital now consists only of the stock that S\&Ls and other institutions have had to buy in order to be members of the Home Loan Bank System and to obtain advances. Members can withdraw from the System and sell

loan-to-value ratios, showing a strong positive correlation, see Price Waterhouse (1990) and Hendershott and Schultz (1993), and the fiterature cited therein. For a mote detalled discussion of the 1990 FHA legislation, see Weicher (1992). 
their stock back to their Home Loan Bank, subject to an advance notice requirement of six months. Thus, it is problematic whether the capital would be available if individual Home Loan Banks began to incur losses. The members have an incentive, and a right, to withdraw their capital just when it is most needed.

But the Home Loan Banks have so little capital because of public policy. They had $\$ 2$ billion in retained earnings until FIRREA took that money to cover part of the cost of S\&L failures. FIRREA also required them to contribute $\$ 300$ million per year out of their future earnings. That is why the only capital they now have is the stock owned by the members. It is going to be difficult to build capital through new retained earnings. Even if Congress were to repeal the $\$ 300$ million annual contribution, the S\&Ls and probably the newer members are likely to prefer having this money passed through as dividends rather than remaining as retained earnings, which could be taken away again. In their studies of the Home Loan Banks, both the General Accounting Office and the Clinton Administration have argued that they need more capital, but neither has offered a specific proposal for raising it.

\section{Countercychical Support for Housing Construction}

The emphasis on safety and soundness creates a clear potential conflict with the traditional countercyclical objective of the housing finance system. This is most obvious with respect to the GSEs, where it was explicitly discussed in evaluating the adequacy of their present capital. In its annual reports as regulator of FNMA and FHLMC prior to legislative consideration of a new capital standard, HUD used a Depression scenario to assess capital adequacy, based on one used by Moody's to rate private mortgage insurers. HUD concluded that neither GSE could survive 10 years of the Depression scenario, but

26 These results are for 1991, as reported in U.S. Department of Housing and Urban Development (1992a, 1992b). Similar tests for 1990 show that FHLMC could survive six years and FNMA seven (U.S. Department of Housing and Urban Development, 1991b). The 1991 test is more detaifed and sophisticated. The test is stringent: it includes a 10 percent dectine in house prices for four straight years, for example. It is necessany to survive to years of the Moody's Depression scenario to qualify for an AAA rating; very few financial institutions are rated AAA. The HUD stress test is not identical to the Moody's scenario, although it is closely modeled on the scenario. Thus, it cannot be said that the GSEs would or would not receive an AAA rating from Moody's, or conversely that any other financial institution would or would not survive 10 years of the HUD stress test. both could last six years. ${ }^{26}$ This analysis assumed that they continued to be active in the mortgage market during the Depression to the same extent as previously; FNMA and FHLMC could survive a full 10 years of the Depression scenario, if they immediately suspended operations at the beginning of the Depression. In response, the GSEs stated that they would in fact cease buying mortgages immediately. ${ }^{27}$ This, of course, raises the question of whether they could recognize the onset of a depression immediately (a delay of two years would be enough to cut the period of survival from 10 to six years for both GSEs). The 1992 legislation accepted the GSE position on at least an interim basis. The stress test must assume that the GSEs accept no new business until the General Accounting Office and Congressional Budget Office complete studies of the appropriate new business assumptions. The studies are due in November 1995. The GSEs have also said they would increase their guarantee fees if necessary to remain solvent, but it is not easy to raise prices during a recession.

It should be possible for a GSE to buy mortgages in periods of high interest rates, earn a profit if rates decline, and perhaps moderate fluctuations in housing production in the process. The opportunity to profit from interest rate declines is limited, but not eliminated, by the prepayment option. On the other hand, countercyclical behavior may result in credit risk. If the quality distribution of loans offered in a recession is the same as during an expansion, then it is necessary to buy lower quality mortgages in order to be actively countercyclical.

The potential conflict has been discussed in every downturn. The legislative changes probably heighten it. The GSEs still have Charter Act responsibilities to "provide ongoing support to the mortgage market," but a capital standard that assumes they do not.
An AAA rating is not likely, however. In 1991 Standard and Poor's evaluated both GSEs at the request of the Treasury, rating FHLMC as A+ and FNMA as A- on the assumption that the GSES did not have agency status, which in fact they do.

${ }^{27}$ The reaction of the GSES appears in U.S. Department of Housing and Urban Development (1991b). 
At present these issues are hypothetical, but in a severe downturn they would become real. They would then attract policymakers' attention and perhaps result in further changes.

\section{"Underserved" Aroas and Groups}

The traditional goal of making mortgage credit equally available across the country has taken new forms in FIRREA and the GSE legislation. The focus of concern has shifted from regions to communities, particularly low-income urban neighborhoods and those with predominantly minority residents, and also to individuals.

Explicit subsidies through the housing finance system are being provided and proposed to meet this goal. FIRREA required the Home Loan Banks to subsidize low-income housing directly by allocating 20 percent of their profits to a new Affordable Housing Program, with a minimum annual amount starting at $\$ 50$ million and increasing to $\$ 100$ million by 1995 . This is essentially another tax on the Home Loan Banks and through them the S\&Ls. The Clinton Administration's report on the Home Loan Bank System goes further and proposes a specific mandate to facilitate mortgage lending to lowerincome families and targeted populations. This would be a new role for the Home Loan Banks.

Support for low- and moderate-income housing has been one of the purposes of FNMA and FHLMC, as stated in their Charter Acts. ${ }^{28}$ This became the major Congressional concern in 1992, once the Administration and the GSEs agreed on a capital standard. The law sets two general goals that certain percentages (to be determined by the HUD Secretary) should be for units occupied by families with incomes below median, and for housing in central cities. Both goals include rental housing as well as homes. ${ }^{29}$ The law allows a number of acceptable reasons for not meeting any goal in a given year, and a multi-year regulatory process before any sanctions could be imposed for falling short.
The law also sets transition goals. Each GSE is to have at least 30 percent of its purchases for housing occupied by families below median income by 1994 , rising in two steps from their 1992 levels. This is about the share of the conventional conforming loan market consisting of buyers in this income range. The GSEs have not come very close to this percentage in the past for single-family houses; both were below 25 percent in 1991. Nearly all apartments, however, are affordable by families of median income by the rules of thumb set forth in the legislation. Both GSEs met the 1993 targets established by HUD.

Similar transition goals were established for central cities, and in this case neither GSE met the 1993 goal. Under HUD's regulations they are now required to file housing plans to describe how they will meet them in the future.

These housing goals pose another potential conflict between the safety and soundness of the housing finance system (and also the financial interests of the private and quasi-private housing finance institutions) and a public purpose which is becoming increasingly prominent. Both the GSEs and the Home Loan Banks have pointed out the conflict. The issue is more serious for the Home Loan Banks because they must fund the Affordable Housing Program. This requirement, like the $\$ 300$ million contribution to the cost of S\&L resolutions, has been used by the Home Loan Banks to justify making investments with the funds that they borrow on the capital markets as the demand for advances has fallen, and thus perhaps to undertake new types of risk.

FNMA and FHLMC are required only to buy loans for moderate-income housing, not to provide subsidies, and they need not lower their underwriting standards. The general conclusion of the mortgage default literature is that default is largely a function of the loan-to-value ratio on the mortgage and not closely related to either the value of a home or the income of the buyer. ${ }^{30}$ But even if moderate-income housing turned out

${ }^{30}$ See Hendershott and Schultz (1993) and the literature cited therein. Hendershott and Schultz do find that foreclosures on FHA-insured loans are inversely related to loan size, which they attribute to differential underwriting standards or house price appreciation rates. The latter explanation might indicate greater risk for small loans.
${ }^{28}$ Both GSEs are required "to provide ongong assistance to the secondary market for residential mortgages (including activities relating to mortgages on housing for low- and moderate-income families involving a reasonable economic return that may be less than the return earned on other activities)..." See 12 U.S.C. $\$ 1716$.

29 The law also sets a special affordable housing goal that 1 percent of each GSE's purchases should be for housing affordable to low-income families or located in low-income neighborhoods, with allocated shares for single-family and multitamily housing. 
to be riskier, it would be possible for the GSEs to take more risk than the S\&Ls, given their lower cost of funds. The charter acts and the legislation seem to expect that the GSEs will use their agency status to make loans to moderate-income buyers, without jeopardizing their safety and soundness. The Administration's proposed lower-income mandate for the Home Loan Banks takes a similar view, stating that collateral requirements should not be relaxed to meet the mandate.

\section{REGUILATORY YSSUES}

\section{The Structure of Regulation}

At the same time that capital standards were being raised for most entities within the system, all of the private institutions were given new regulators. The Bank Board was abolished and its duties parcelled out among several agencies.

Some of the potential conflicts between public purpose and safety and soundness are reflected in the new regulatory structure. The 1992 GSE legislation divided authority between the Secretary of HUD and the Director of a new Office of Federal Housing Enterprise Oversight (OFHEO), which is formally part of HUD but is effectively independent of the Secretary. The Director regulates for safety and soundness; the Secretary establishes, monitors, and enforces the housing goals and regulates the GSEs in all areas other than safety and soundness. For example, the Secretary rather than the Director approves new programs, and the Secretary rather than the Director raised the issue of whether the GSEs had to reduce their maximum mortgage amount when the conforming loan limit declined last year. The effectiveness of this relationship has not yet been tested, since the Office is still in the formative stage and has not yet had to issue any of the regulations required by the law.

Both the GAO and the Administration studies of the Home Loan Banks have recommended that they be regulated by OFHEO. At present they are regulated by the Federal Housing Finance Board, created in FIRREA as an after" thought for that sole purpose. The ostensible reason for abolishing the Bank Board was that it acted as an advocate for the industry it was supposed to regulate. The risk that the regulated entities would capture the regulator would seem to be still greater for the Federal Housing Finance Board, with nothing to do but regulate the 12 Home Loan Banks, and for OFHEO, regulating only the two GSEs. It is probably preferable to have one regulator for all 14 institutions, rather than two, although FNMA and FHLMC do not favor sharing their regulator. Whether that proposal is adopted, it seems likely that the regulatory structure of the system will be revised again.

\section{Is There A Future for Specialized Porfolio Lenders?}

Public policy has wrestled for two decades with the question of whether specialized mortgage portfolio lenders can exist. In the 1970s policymakers decided they could and tried to keep the S\&Ls operating as they always had in the face of inflation and new competition. In the 1980s policy reversed itself, and S\&Ls were given broad new asset powers. In the 1990 s policy has reversed itself again. FIRREA adopted the premise that deregulation caused the S\&L. failures, a view not shared by most economists. ${ }^{31}$ It explicitly took away some of the powers granted in 1980-82 and required S\&Ls to put a higher percentage of their assets in mortgages and housing investments to keep their tax advantages, although the latter restriction was somewhat relaxed in $1991 .{ }^{32}$ S\&Ls are not forced to be specialized housing portfolio lenders, however; the new capital rules give them an incentive to move away from portfolio lending by requiring only 40 percent as much capital against MBSs issued by the GSEs as against whole mortgages.
${ }^{31}$ White (1991) favors deregulation, but says it came 15 years too tate and should have been accompanied by stronger safety and soundness regulation, and by risk-adjusted deposit insurance premiums. He reviews the literature showing that losses were positively related to use of the new powers. Barth (1991) favors deregulation but says that it contributed to the problems of some S\&Ls. Kane (1989) argues that deregulation did not cause the problems of $\$ \& L s$ and re-regulation would not solve them, but goes on to say that deregulation expanded opportunities for poorly managed S\&ls to fail, as well as allowing well-managed ones to rebuild their net worth. Rudolph (1989) analyzed the subsequent behavior of S\&Ls that were insolvent in 1982 and found that traditional housing lenders were more likely to be insolvent in 1982-83, but less likely in 1986, which suggests that among insolvent S\&Ls, at least, those taking advantage of the new powers were less successful than those which "stayed in housing."

32 White (1991) notes, however, that at the same time these provisions were enacted, many members of Congress were saying that S\&ls should be more like commercial banks. 
Meanwhile, the GSEs are thriving in part because they are specialized lenders-very large S\&Ls, in that sense-as well as secondary market agencies. Their portfolio operations are quite profitable: Almost three-quarters of FNMA's revenue, and almost half of FHLMC's, came from their portfolios in 1992. FHLMC has recognized this since FIRREA gave it the same powers and incentives as FNMA; it is behaving similarly, expanding its portfolio by 70 percent and announcing a business objective of further rapid growth. FHLMC was already the fourth largest portfolio lender in the United States, although its portfolio always has been small relative to its securities volume. The specialized portfolio lender is alive and functioning to a greater extent than is generally recognized.

Several factors contribute to the GSEs' success as portfolio lenders. A number of recent studies conclude that the 20 to 35 basis point difference between the conforming market and the jumbo market is the margin between profit and loss for S\&Ls, on average. The cost advantage of the GSEs is attributed to the lower capital requirements they face, the tax exemptions and smaller regulatory burdens granted them by their federal charters, the fact that they do not have to pay deposit insurance premiums or help to fund the resolution of failed S\&Ls, and economies of scale..$^{33}$ The first two factors are benefits conferred. explicitly by act of Congress.

Macroeconomic conditions may also contribute to the GSEs' recent success. If inflation is erratic and unanticipated, it is probably not possible to survive as a specialized portfolio lender, as FNMA and the S\&Ls showed during the 1970 s and early $1980 \mathrm{~s}$. If inflation is low and stable, it is apparently still possible to be a specialized portfolio lender, as the same institutions showed when inflation receded after 1982 and both FNMA and a large number of S\&Ls became profitable once again. FNMA especially was saved by disinflation. It gambled on a decline in interest rates (there was not much to lose from such a gamble, from the stockholders' point of view), buying mortgages in large volume, and it benefitted greatly when rates fell. Its net worth became positive in 1985 . It has tried to prevent a similar problem in the future. A HUD analysis in 1991 concluded that it has effectively hedged against interest rate risk by changing the duration of its liabilities, even though most of its portfolio consists of fixed-rate mortgages.

It is doubtful if S\&Ls could do the same thing, given their higher costs. They may be able to prosper as portfolio lenders specializing to some extent in fixed-rate mortgages by accepting interest rate risk, if inflation remains low and if the yield curve remains upward sloping. They may also survive as ARM lenders.

The broader geographic authority of the GSEs may have been important in the 1980s. S\&L failures since deregulation have been concentrated in states which suffered severe recessions, notably Texas but also other energy and farm states. The decline in domestic crude oil prices between 1982 and 1989 precipitated a regional recession in which commercial real estate values in the Southwest fell by one-third. (Over the same period, they rose nationally by about 10 percent.) Defaults on home mortgages and other real estate rose rapidly. The geographic restrictions on S\&L portfolios meant that the bad investments and loans were held in the portfolios of institutions in those states. One-fifth of the S\&Ls which failed during the 1980 s were located in Texas and they accounted for half of the losses. Deposit insurance turned the regional failures into a national problem.

It is now possible for an S\&L, like a GSE, to make or buy loans anywhere in the country. This may be significant. Both FNMA and FHA survived the Texas recession and other regional problems during the mid-1980s. Both sustained losses, but neither was driven to a negative net worth position. Their experience suggests that national portfolio lenders - in effect, national S\&Ls-could be viable. But the cost advantages of the GSEs would remain.

\section{GSE Powers}

The competitive advantages conferred on the GSEs by agency status raise the question of their role as potential competitors in markets beyond their current activities. This has been a recurring issue for FNMA since it was privatized, when the Secretary of HUD was given new program approval authority. It has become an issue for FHLMC

${ }^{33}$ See Cotterman (1994) and McNulty and Pearce (1994) for discussions of the literature. Goodman and Passmore (1992) calculate that the difference in capital requirements alone lowers the GSEs' costs by about 35 basis points. 
since FIRREA. Typically, FNMA has sought legislative authority from Congress if the Secretary has denied or deferred approval. Usually, but not always, Congress has given approval.

The most contentious instance is REMICs. The Tax Reform Act of 1986 created these securities and authorized FNMA and FHLMC to issue REMTCs backed by conventional mortgages, subject to the approval of their regulators. ${ }^{34}$ Both agencies sought approval, over the strong objections of Wall Street securities issuers, who argued that they could enter this market if the agencies did not, but could not compete with them. The Federal Home Loan Bank Board originally decided not to allow FHLMC to issue REMICs, but HUD (under pressure from Congress) eventually allowed FNMA to issue them on a temporary basis, which became permanent in 1988, and FHLMC was allowed to issue them in 1988.

FNMA has also sought to move beyond mortgage purchase and securitization, with less success. In 1985 it proposed to buy bonds collateralized by mortgages that would be issued by financing subsidiaries of financial institutions. In 1990 it requested approval of a program to buy debt obligations secured by conventional mortgages, or securities backed by such mortgages. The former proposal brought objections from investment bankers and the Senate Banking Committee chaiman and ranking minority member, as being financing transactions rather than mortgage pur" chases, and HUD did not approve it. The latter would have placed FNMA in competition with the Home Loan Banks by letting it issue advances against mortgage collateral, and HUD again denied approval. ${ }^{35}$
FNMA has also undertaken or considered activities that are ancillary to its secondary market operations but that are already provided by private firms. In the mid-1980s, it raised the possibility of establishing a mortgage insurance subsidiary, in competition with the private mortgage insurance industry. In 1985 it acquired a computer software firm with the intent of producing and selling a loan origination and servicing program. ${ }^{36}$

The GSEs have strongly opposed any regulatory limitation on their powers. This was a major issue in the 1992 legislation. Ultimately, the HUD Secretary retained the authority to deny approval for a new program if he or she determines that the program is "not in the public interest," but the Secretary has to act within 45 days, and the law prescribes an appeals process which is heavily weighted toward the GSEs. The law also gives the GSEs broad authority to buy any kind of home mortgage, limiting the Secretary's regulatory discretion. ${ }^{37}$ There is no reason to think that the GSEs will not attempt to extend their activities in the future, so the demarcation of authority between different institutions will probably continue to be a recurring issue.

\section{CONCLUSTON}

One public policy issue which appears to be resolved is the desirability of a housing finance system to allocate credit to housing. This is a change from recent years. For about a decade beginning in the late 1970s, there was extensive public discussion about dismantling the system on the grounds that it was becoming too expensive for society to continue allocating credit to housing, in two senses. Household investment in housing was growing rapidly in response to
${ }^{34}$ REMLCs have tax advantages over CMOs and were expected to be a major innovation in mortgage securities.

35 HUD also denied approval on grounds that the program involved significant risks to all parties, including the federal government, and could adversely affect FNMA's safety and soundness since it could affect FNMA's needs for capital. The transactions woufd have allowed financial institutions to defer recognition of economic losses and encourage leveraging, possibly increasing the risk of bankruptcy by the institution. Denial of new programs on safety and soundness grounds has been relatively infrequent.

36 The regulatory issues raised by new activities between 1980 and 1985 are described in U.S. Department of Housing and Urban Development (1987), the proposal to purchase debt obligations secured by conventional mortgages in U.S. Department of Housing and Urban Development (1991a).

${ }^{37}$ in 1970 FNMA sought and received regulatory approval from Secretary George Romney to begin a program of buying conventional first motgages on single-family homes. At the time, virtually the only conventional mortgages issued were standard mortgages. As new instruments were developed in the 1980s. FNMA claimed the atthority to buy any kind of conventional first mortgage under the "Romney letter," such as ARMs and balloon morigages with different risk characteristics than the standard mortgage. Proposed HUD regulations issued in 1990 would have revoked this broad interpretation. FNMA objected to the regulations, and they wefe superseded by the 1992 legislation. 
inflation in the late 1970 s, with concomitant underinvestment in productive capacity, and the growing problems of the S\&Ls were threatening to impose direct costs on taxpayers.

A number of proposals were offered to address these concerns. The Financial Reform Act considered by the House of Representatives in 1976 would have turned the S\&Ls into commercial banks. The Reagan Administration offered budget proposals to levy fees on the GSEs, which could have been set at a level to cover the market value of agency status. There were several studies of privatizing one or both of them in the mid-1980s.

But interest has faded since then. During consideration of FHA reform, no one (including its competitors) made any suggestion to close FHA down or turn it over to the private sector. Most importantly, there was no real interest in privatizing either GSE in the extended process of writing the 1992 legislation. The closest thing to it was an amendment offered by Rep. Jim Leach (R.-Iowa) on the floor of the House of Representatives, which would have set higher capital standards and eliminated some of the GSEs' privileges. The amendment lost on a 298-119 vote. No comparable proposal was mentioned in the Senate.

Five years after FIRREA and 15 years after public recognition that the New Deal housing finance system was no longer viable, the United States has a very different system. But the new system still has the same purposes as the old one, broadly speaking, and if anything the inherent conflicts between the purposes of the system and the safety and soundness of the individual institutions in it are more sharply drawn. While the spectacular problems of the S\&Ls have attracted most of the recent attention, their role has sharply diminished, and the important issues in the future are likely to involve the GSEs.

\section{WHELENCWS}

Barth, James R. The Great Savings and Loan Debacle. American Enterprise Institute, 1991.

Bodfish, Morton. History of Building and Loan in the United States. United States Building and Loan League, 1931.

Brewer, Elijah, III "Full-Blown Crisis, Hall-Measure Cure," Economic Perspectives (November/December 1989), pp. 2- $\uparrow 7$.

Brumbaugh, R. Dan, Jr. Thrifts Under Siege: Restoring Order to American Banking. Ballinger, 1988.
Cotterman, Robert F. 'The Effects of FHLMC's and FNMA's Mortgage Activities," in U.S. Department of Housing and Urban Development, Report to Congress on the Federal Home Loan Bank System, vol. 2: Analytical Studies. U.S. Department of Housing and Urban Development, 1994.

Fredrikson, E. Bruce. "The Geographic Structure of Residential Mortgage Yields," in Jack M. Guttentag, ed., Essays on interest Rates, vol. Il. Columbia Uriversity Press, 1971.

Goodman, John L., Jr., and S. Wayne Passmore. "Market Power and the Pricing of Mortgage Securitization." Federal Reserve Board Finance and Economics Discussion Paper No. 187 (March 1992).

Grebler, Leo, "An Assessment of the Performance of the Public Sector in the Residential Housing Market: 1955 1974, in Robert M. Buckley, John A. Tuccillo, and Kevin E. Vilani, eds., Capital Markets and the Housing Sector. Ballinger, 1977.

David M. Blank, and Louis Winnick, Capital Formation in Residential Real Estate. Princeton University Press, 1956.

Hendershott, Patric H., and Willam R. Schultz. "Equity and Nonequity Determinants of FHA Single Family Mortgage Foreclosures in the 1980s." Journal of the American Real Estate and Urban Economics Association (winter 1993). pp. 405-30.

, and dames D. Shilling. "The Impact of the Agencies on Conventional Fixed-Rate Mortgage Yields," Joumal of Real Estate Finance and Economics (June, 1989), pp. 101-15.

, and Kevin E. Villani. "Measurement of the Spreads between Yields on Various Mortgage Contracts and Treasury Securities," AREUEA Joumal (winter 1983), pp. 476-89.

and Robert Van Order. "Integration of Mortgage and Capital Markets and the Accumulation of Residential Capital," Regional Science \& Urban Economics (May 1989), pp. $189-210$.

ICF, Incorporated. Effects of the Conforming Loan Limit on Mortgage Markets. U.S. Department of Housing and Urban Development, March 1990.

Jaffee, Dwight M., and Kenneth T. Rosen. "Mortgage Credit Avallability and Residential Construction," Brookings Papers on Economic Activity (1979, No. 2), pp. 333-76.

Jones, Sidney L. The Development of Economic Policy: Financial Institution Reform. Graduate School of Business Administration, University of Michigan, 1979.

Kane, Edward J. The Gathering Crisis in Federal Deposit Insurance. MIT Press, 1985.

"The Looting of FSLIC: What Went Wrong?" Ohio State University College of Business Working Paper $89-3$ (January 1989).

, and Chester Foster. "Valuing and Eiminating Subsidies Associated With Conjectural Government Guarantees of FNMA Liabilities, ${ }^{*}$ College of Adrninistrative Sciences Working Paper 86-71, Ohio State University (1986).

Karson, Marvin J. Patricia M. Rudfolph, and Leonard V. Zumpano. "Inter-Regional Differences in Conventional Mortgage Terms: A Test of the Efficlency of the Residential Mortgage Market," paper presented at the American Real Esta:e and Urban Economics Association, 1986. 
Kaserman, David L. "An Econometric Analysis of the Decline in Federal Mortgage Default insurance," in Robert M. Buckley, John A. Tuccillo, and Kevin E. Villani, eds., Capital Markets and the Housing Sector. Ballinger, 1977.

Kautman, George. "Impact of Deregulation on the Mortgage Market," in Housing Finance in the Eighties: Issues and Options. Federal National Mortgage Association, 1981.

Kaufman, Herbert. "FNMA and the Housing Cycle: Its Recent Contribution and Its Future Role in a Deregulated

Environment," in U.S. General Accounting Office, The Federal National Mortgage Association in a Changing Economic Environment. U.S. General Accounting Office, 1985

King, A. Thomas, and David Andrukonis. "Who Holds PCs?" Secondary Mortgage Markets (February 1984), pp. 12-17.

McNulty, James $\mathrm{E}_{\text {, }}$ and James Pearce. "An Economic Evaluation of Specialized Housing Lenders and the Qualifted Thrift Lender Test: A Review of the Literature," in U.S. Department of Housing and Urban Development, Report to Congress on the Federal Home Loan Bank System, vol. 2: Analytical Studies. U.S. Department of Housing and Urban Development, 1994.

Morton, J.E. Urban Mortgage Lending: Comparative Markets and Experience. Princeton University Press, 1956.

Price Waterhouse. An Actuarial Review of the Federal Housing Administration's Mutual Mortgage Insurance Fund. Price Waterhouse, 1990.

Rudolph, Patricia M. "The Insolvent Thrifts of 1982: Where Are They Now?" AREUEA Joumal (winter 1989), pp. 450-62.

, Leonard V. Zumpano, and Marvin J. Karson. "Mortgage Markets and Inter "Regional Differences in Conventional Mortgage Terms," AREUEA Journal (spring 1982), pp. 94110 .

Sauinier, R,J., Harold G. Halcrow and Neil H. Jacoby. Federal Lending and Loan Insurance. Princeton University Press, 1958
Tuccillo, John A., Robert Van Order, and Kevin E. Villani. "Homeownership Policies and Mortgage Markets, 1960 to 1980," Housing Finance Review (January 1982), pp. 1-21.

U.S. Department of Housing and Urban Development, 1991 Report to Congress on the Federal Home Loan Mortgage Corporation. HUD, $1992 \mathrm{a}$.

1991 Report to Congress on the Federal National Mortgage Association. HUD, $1992 \mathrm{~b}$.

1990 Report to Congress on the Federal National Mortgage Association. HUD, $1991 \mathrm{a}$.

Capitalization Study of the Federal National Mortgage Association and the Federal Home Loan Mortgage Corporation. HUD, 1991b.

1989 Report to Congress on the Federal Home Loan Mortgage Corporation. HUD, 1990a.

1988-89 Report to Congress on the Federal National Mortgage Association. HUD, 1990b.

1986 Report to Congress on the Federal National Mortgage Association. HUD, 1987.

U.S. General Accounting Office. Federal Home Loan Bank System: Reforms Needed to Promote its Safety, Soundness, and Effectiveness. U.S. General Accounting Office, GAO/GGD-94-38, December 1993.

Weicher, John C. "The Future Structure of the Housing Finance System," in William S. Haraf and Rose Marie Kushmeider, eds., Restructuring Banking and Financial Services in America. American Enterprise Institute, 1988.

"FHA Retorm: Balancing Public Purpose and Financial Soundness," Journal of Real Estate Finance and Economics (March 1992), pp. 133-50.

White, Lawrence J. The $S \& L$ Debacle. Oxford University Press, 1991. 